\title{
Percent of Monocytes
}

National Cancer Institute

\section{Source}

National Cancer Institute. Percent of Monocytes. NCI Thesaurus. Code C159480.

A quantitative measurement of the percent of monocytes compared to the number of total cells present in a sample. 